\title{
Ocena skuteczności stosowania wybranych leków przeciwbólowych po zabiegach operacyjnego usuwania zatrzymanych dolnych trzecich zębów trzonowych
}

\author{
Evaluation of the efficacy of selected analgesics after surgical extraction \\ of impacted lower third molars
}

\author{
Katedra i Klinika Chirurgii Stomatologicznej \\ Uniwersytet Medyczny im. Karola Marcinkowskiego w Poznaniu
}

DOI: http://dx.doi.org/10.20883/df.2016.21

\begin{abstract}
Streszczenie
Wprowadzenie. Zabieg operacyjnego usuwania zatrzymanych dolnych zębów mądrości często wiąże się z pooperacyjnym procesem zapalnym. W celu łagodzenia bólu pooperacyjnego stosowane są głównie niesteroidowe leki przeciwzapalne w różnych dawkach i w różnych schematach terapeutycznych. Ich skuteczność można oceniać za pomocą specjalnie opracowanych w tym celu skal: wizualno-analogowej, numerycznej i werbalnej.

Cel. Ocena skuteczności działania przeciwbólowego ibuprofenu, ketoprofenu i nimesulidu w 1 i 3 dniu od zabiegu operacyjnego usunięcia zatrzymanego dolnego zęba mądrości. Dodatkowym celem pracy było określenie przydatności terapeutycznej skali wizualno-analogowej, numerycznej i werbalnej w pooperacyjnej kontroli bólu.

Materiał i metody. W badaniach uczestniczyło 58 pacjentów (36 kobiet i 22 mężczyzn), w wieku od 17 do 41 lat, którzy zostali poddani zabiegowi operacyjnego usunięcia zatrzymanego dolnego zęba mądrości. Po zabiegu 20 osób przyjmowało ibuprofen w dawce $0,2 \mathrm{~g}$ co 8 godzin, 19 osób ketoprofen w dawce $0,1 \mathrm{~g}$ co 8 godzin i 19 osób nimesulid w dawce 0,1 g co 12 godzin. Każdy pacjent dwukrotnie (w 24 godzinie i 72 godzinie od zabiegu) oceniał ból pooperacyjny w trzech skalach: wizualno-analogowej, werbalnej i numerycznej.

Wyniki. Nie ma istotnych statystycznie różnic w natężeniu bólu pooperacyjnego u pacjentów przyjmujących badane leki. W każdej skali natężenie bólu w 72 godzinie od zabiegu jest niższe niż w 24 godzinie od zabiegu. Im wyższa wartość bólu pacjenta wyrażana w skali wizualno-analogowej, tym wyższe jego odczuwanie w skali numerycznej. Im wyższa wartość bólu pacjenta w skali werbalnej, tym wyższe jego odczuwanie w skali numerycznej.

Wnioski. W wyborze leków przeciwbólowych powinniśmy kierować się indywidualną oceną stanu zdrowia pacjenta, indywidualnymi wskazaniami i przeciwwskazaniami, a w mniejszym stopniu przewidywanym przez nas efektem działania przeciwbólowego. Stosowanie leków przeciwbólowych w okresie pooperacyjnym zmniejsza dolegliwości bólowe, pozwala opanować stan zapalny i przyczynia się do skrócenia czasu gojenia. Skale są przydatne w pooperacyjnej kontroli bólu i monitorowaniu jego natężenia, a ich przydatność terapeutyczna jest równorzędna.
\end{abstract}

Słowa kluczowe: leki przeciwbólowe, leki przeciwzapalne, ból, skala wizualno-analogowa, zęby mądrości.

\begin{abstract}
Introduction. Surgical extraction of impacted lower wisdom teeth is often associated with post-operative inflammatory processes. In order to alleviate post-operative pain non-steroid anti-inflammatory drugs (NSAIDs) are predominantly used. Their effectiveness can be assessed using, e.g., visual analogue, numerical and verbal scales.

Aim. Evaluate the effectiveness of the analgesic effect of ibuprofen, ketoprofen and nimesulide on the 1st and 3rd day after surgery. Additionally, the study aimed to determine the therapeutic usefulness of visual analogue, numeric and verbal scales in post-operative pain control.

Material and Methods. The study involved 58 patients (36 women and 22 men), 17 to 41 years old, who underwent surgical extraction of an impacted lower wisdom tooth. After surgery, 20 patients were treated with $0.2 \mathrm{~g}$ of ibuprofen every 8 hours, 19 individuals with $0.1 \mathrm{~g}$ of ketoprofen every 8 hours, and 19 with $0.1 \mathrm{~g}$ nimesulide every 12 hours. Each patient evaluated their post-operative pain twice; 24 hours and 72 hours after surgery; using visual analogue, verbal and numeric scale.

Results. There was no statistically significant difference in the intensity of post-operative pain in patients treated with the various drugs. In each scale pain intensity in the 72 nd hour after surgery was lower than in the 24th hour. The higher the score of pain in the visual analogue scale, the higher the patient's score of pain in the numerical scale; and the worse the patient's pain in the verbal scale, the higher the values in the numerical scale.

Conclusions. The study shows that choice of pain-killer should be guided by an individual assessment of the patient's health, individual indications as well as contraindications; and to a lesser extent by the expected effects of analgesia. The use of analgesics reduces pain, enables the control of inflammation and helps shorten the healing time. Pain assessment scales are useful in post-operative pain control and monitoring pain levels.
\end{abstract}

Keywords: analgesics, anti-inflammatory drugs, pain, visual analog scale, wisdom teeth. 


\section{Wprowadzenie}

Usuwanie zatrzymanych zębów trzonowych należy do najczęściej wykonywanych zabiegów z zakresu chirurgii stomatologicznej. Ten dość powszechny zabieg wiąże się często z pooperacyjnym procesem zapalnym, któremu towarzyszy ból, obrzęk, szczękościsk i upośledzenie funkcji żucia. Jednym ze sposobów zwalczania tych dolegliwości jest stosowanie w okresie pooperacyjnym leków przeciwzapalnych i przeciwbólowych. Zgodnie z drabiną analgetyczną przedstawioną przez WHO lekami pierwszego rzutu w zwalczaniu bólu, m.in. bólu pooperacyjnego, są niesteroidowe leki przeciwzapalne (NLPZ) albo acetoaminofen lub kombinacja obu. W przypadku ich nieskuteczności należy zastosować słaby opioid w ewentualnym skojarzeniu z NLPZ lub acetoaminofenem. Na najwyższym stopniu drabiny analgetycznej znajdują się silne leki opioidowe w ewentualnym skojarzeniu z NLPZ lub acetoaminofenem [1]. Na każdym etapie farmakoterapię bólu można wspomagać lekami adjuwantowymi. Oprócz NLPZ w zwalczaniu objawów zapalnych stosowane są leki steroidowe. NLPZ różnią się siłą i czasem działania przeciwbólowego, budową chemiczną oraz mechanizmem działania, który ma również wpływ na ich efekty uboczne. Podstawą ich działania przeciwzapalnego jest hamowanie enzymu cyklooksygenazy (COX). Wyróżniamy trzy typy cyklooksygenazy: COX-1, COX-2 i COX-3. Leki przeciwbólowe mogą oddziaływać na wszystkie typy COX lub być selektywnymi inhibitorami jednego z nich, co ma swoje implikacje kliniczne. Rozpowszechnionymi lekami blokującymi dwa typy COX (COX-1 i COX-2) są ketoprofen i ibuprofen. Ibuprofen należy do leków krótko- i słabodziałających i w odróżnieniu od innych NLPZ blokujących COX-1 wywołuje nieznaczne efekty uboczne na błonę śluzową przewodu pokarmowego. Może być bezpiecznie stosowany nawet u pacjentów z chorobą wrzodową żołądka i dwunastnicy. Wywołuje także nieznaczne działanie antyagregacyjne [1]. Bezpieczeństwo stosowania ibuprofenu spowodowało, że należy on do ogólnie dostępnych i szeroko rozpowszechnionych analgetyków z grupy leków "over the counter" (OTC). Ketoprofen blokuje COX-1 i COX-2 w równym stopniu, ale wywołuje poważne działanie uboczne na błonę śluzową przewodu pokarmowego i może powodować przedłużone krwawienie pooperacyjne, związane z silnym działaniem przeciwpłytkowym. Z kolei nimesulid należy do selektywnych inhibitorów COX-2 i w związku z tym jest pozbawiony szeregu działań ubocznych, charakterystycznych dla leków blokujących COX-1.
Ból jest objawem subiektywnym i określenie jego intensywności jest niezwykle trudne i uzależnione od indywidualnej wrażliwości. Do oceny bólu wykorzystuje się specjalnie opracowane skale: numeryczną, werbalną i wizualno-analogową [2-6].

\section{Cel}

Celem pracy jest porównanie skuteczności działania przeciwbólowego trzech wybranych leków przeciwzapalnych (nimesulidu, ibuprofenu i ketoprofenu) w pierwszej i trzeciej dobie po zabiegu operacyjnego usuwania zatrzymanych dolnych zębów trzonowych. Dodatkowym celem pracy jest porównanie i ocena przydatności terapeutycznej skali wizualno-analogowej, numerycznej i werbalnej w pooperacyjnej kontroli bólu.

\section{Materiał i metody}

W badaniach uczestniczyło 58 pacjentów (36 kobiet i 22 mężczyzn), w wieku od 17 do 41 lat, którzy zostali poddani zabiegowi operacyjnego usunięcia zatrzymanego dolnego zęba mądrości. Grupę badaną stanowili zdrowi pacjenci, bez alergii na NSLP, nieprzyjmujący aktualnie żadnych leków. Do badania zakwalifikowano w sposób losowy pacjentów, którzy zgłosili się do Kliniki Chirurgii Stomatologicznej celem usunięcia dolnego trzeciego zęba trzonowego. Po zabiegu przez okres 4 dni 20 osób przyjmowało doustnie ibuprofen (in tabl.) w dawce 0,2 g co 8 h, 19 osób przyjmowało doustnie ketoprofen (in tabl.) w dawce $0,1 \mathrm{~g}$ co $8 \mathrm{~h}$ a 19 osób przyjmowało doustnie nimesulid (in susp.) w dawce $0,1 \mathrm{~g}$ co $12 \mathrm{~h}$. Pierwszą dawkę leku przyjęto bezpośrednio po zabiegu, a następne według schematu i w dawce zalecanej dla danego leku. Opuszczenie dawki leku lub wydłużenie odstępu pomiędzy dawkami stanowiło podstawę do wyłączenia $z$ badanej grupy. Doraźne przyjmowanie leku także stanowiło kryterium wyłączenia. Zdyscyplinowanie pacjentów w przyjmowaniu leków weryfikowano poprzez codzienne wizyty kontrolne w okresie pooperacyjnym przez okres trwania badania. Dodatkowo każdy pacjent po zabiegu przyjmował klindamycynę w dawce 0,6 co 12 h. Do oceny bólu pooperacyjnego po okresie 24 godzin i 72 godzin od zabiegu wykorzystano skalę wizualno-analogową, numeryczną i werbalną, w których pacjent określał swoje odczucie bólu. Zastosowano $100 \mathrm{~mm}(10 \mathrm{~cm})$ skalę wizualno-analogową, w której pacjenci zaznaczali swoje odczucia bólowe na podziałce milimetrowej od wartości 0 dla braku bólu, następnie dla kolejnych wartości opisujących wzrastające odczucia bólowe, aż do 10 dla najsilniejszych. W skali werbalnej odpowiedniej cyfrze przyporządkowano określony opis bólu, tj. 0 - brak bólu, 1 - ból łagodny, 2 - ból znośny/umiar- 
kowany, 3 - ból dotkliwy/bardzo silny, 4 - ból nieznośny, 5 - ból nie do wytrzymania. W skali numerycznej pacjent określał swój ból w skali wartości od 1 dla braku bólu do 10 dla bólu o najsilniejszym natężeniu. Równocześnie pacjenci wskazywali na działanie uboczne związane z przyjmowaniem leków przeciwbólowych [2-6].

\section{Metody statystyczne}

Obliczenia statystyczne wykonano za pomocą programu Statistica. Normalność rozkładu weryfikowano testem Shapiro-Wilka. Porównania skuteczności działania leków badano przy pomocy testu Kruskal-Wallisa. Porównania natężenia bólu między 24 a 72 godziną od zabiegu dla wszystkich skal dokonano przy pomocy testu kolejności par Wilxocona. Korelacje miedzy wartościami zmiennymi badano przy pomocy testu korelacji rang Spearmana. Wszystkie wykazane różnice i wyznaczone współczynniki korelacji przyjęto za statystycznie istotne przy poziomie istotności $p \leqslant 0.05$.

\section{Wyniki}

1. Nie ma istotnych statystycznie różnic w natężeniu bólu pooperacyjnego w 24 godzinie i 72 godzinie od zabiegu u pacjentów przyjmujących badane leki.

2. W każdej skali natężenie bólu w 72 godzinie od zabiegu jest niższe niż w 24 godzinie od zabiegu.

3. Im wyższa wartość bólu wyrażana w skali wizualno-analogowej, tym wyższe jego odczu- cie wyrażone przy pomocy skali numerycznej. Im wyższa wartość bólu pacjenta wyrażana w skali werbalnej, tym wyższe jego odczucie wyrażane w skali numerycznej.

\section{Dyskusja}

Ibuprofen należy do najbezpieczniejszych środków przeciwbólowych, od wielu lat z powodzeniem stosowanych w chirurgii stomatologicznej. Stanowi niejednokrotnie punkt odniesienia, względem którego porównuje się skuteczność i bezpieczeństwo stosowania innych NLPZ. Szybko wywołuje efekt analgetyczny, który jednak utrzymuje się krócej w porównaniu z innymi NLPZ. W celu zwiększenia jego działania przeciwbólowego jest kojarzony z acetoaminofenem w schemacie 0,5 g acetoaminofenu i 0,15 g ibubrofenu [7]. Oba środki mają podobną farmakokinetykę i wzajemnie potęgują efekt przeciwbólowy. W naszych badaniach krótkie działanie ibuprofenu nie wpłynęło na zwiększenie odczuwania bólu operacyjnego i nie wymagało uzupełniania terapii przeciwbólowej acetaminofenem. Ibuprofen zastosowany natychmiast po zabiegu i stosowany w zaproponowanym schemacie okazał się równie skuteczny jak nimesulid i ketoprofen. Podobne wyniki uzyskali Lustenberger i wsp., którzy wykazali, że ibuprofen w dawce 400 mg wywołuje podobny efekt analgetyczny jak lornoxicam w dawce 8 mg co 8 godzin przez 4 dni po zabiegach chirurgicznego usuwania zatrzymanych dolnych zębów mądrości

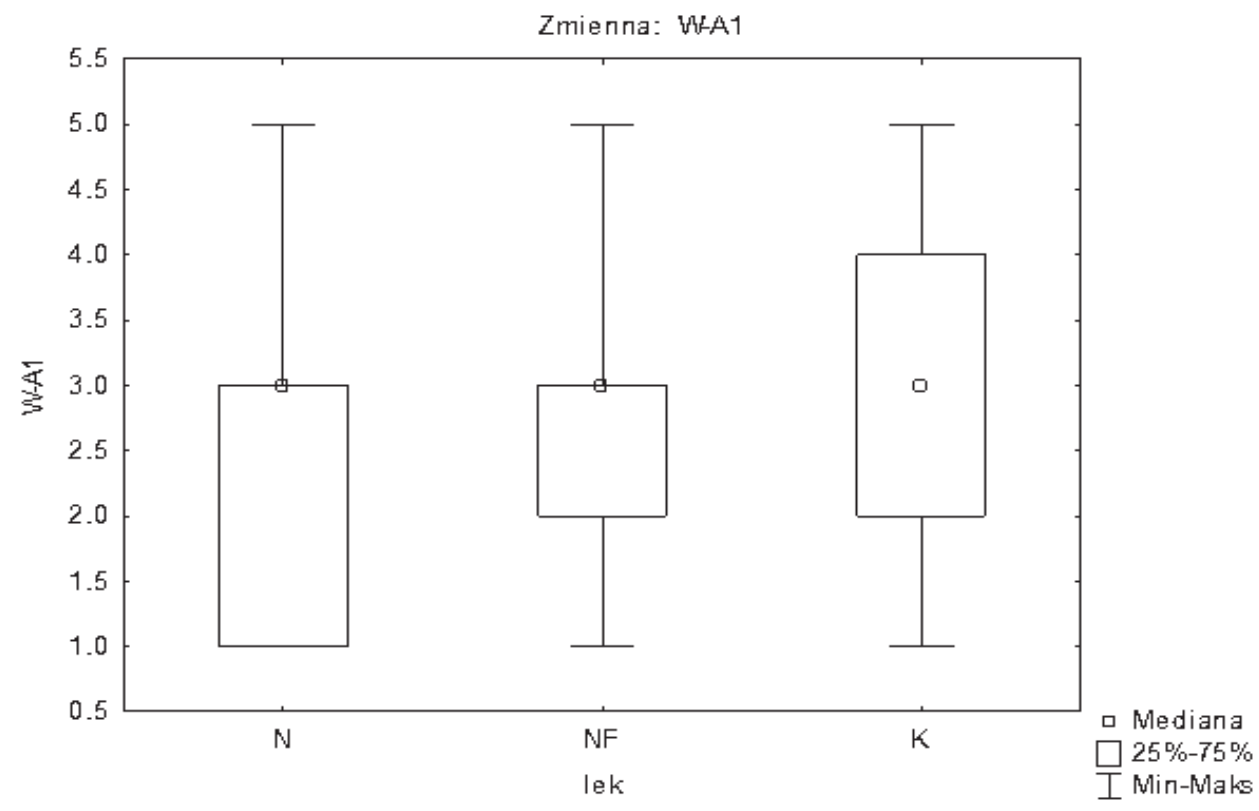

Rycina 1. W-A 1 Skala wizualno-analogowa w 24 godzinie od zabiegu

Figure 1. Comparison of analgesic effectiveness of ibuprofen (NF), ketoprofen (K) and nimesulide (N) in the 24th hour after surgery in visual analog scale. W-A 1 - visual analog scale in the 24th hour after surgery 


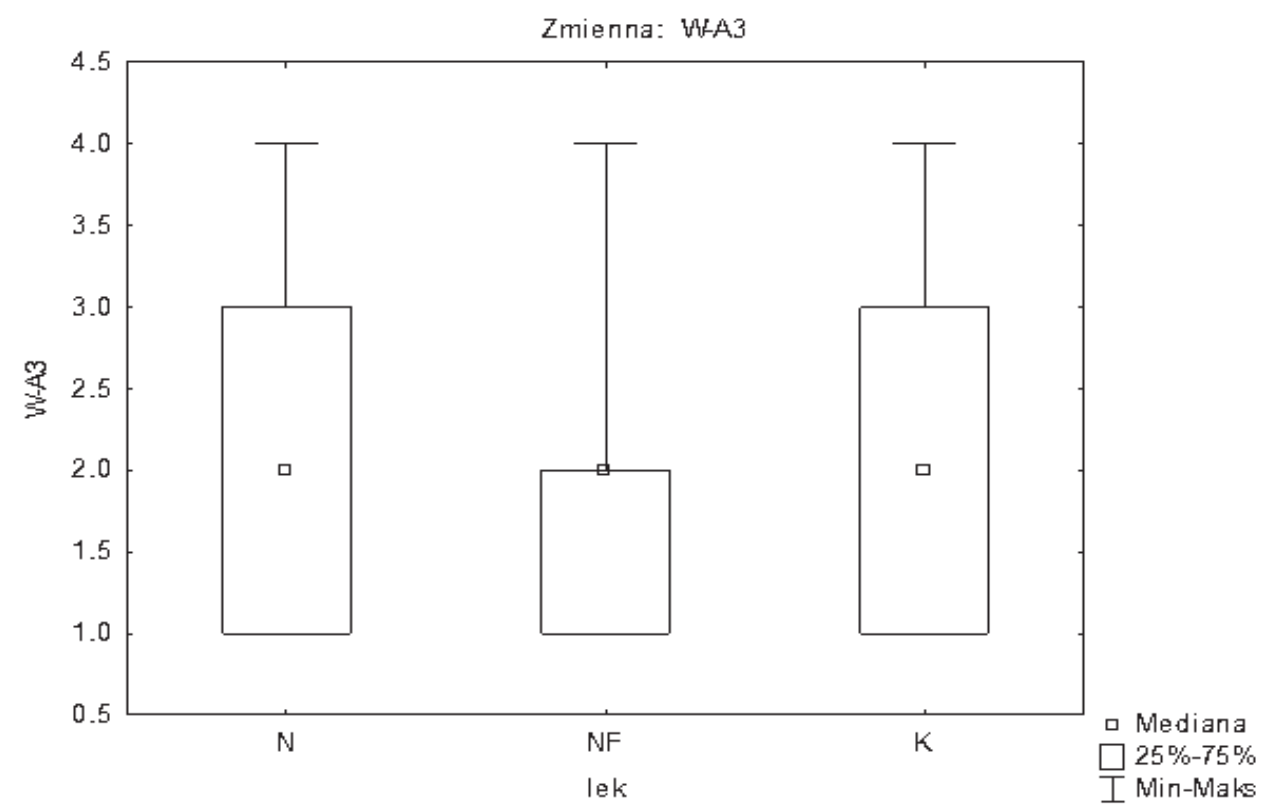

Rycina 2. Porównanie skuteczności działania przeciwbólowego ibuprofenu (NF), ketoprofenu (K) i nimesulidu (N) w skali wizualno-analogowej w 72 godzinie po zabiegu. W-A 3 Skala wizualno-analogowa 72 godzinie od zabiegu

Figure 2. Comparison of analgesic effectiveness of ibuprofen (NF), ketoprofen (K) and nimesulide (N) in the $72 n d$ hour after surgery in visual analog scale. W-A 3 - visual analog scale in the 72nd hour after surgery

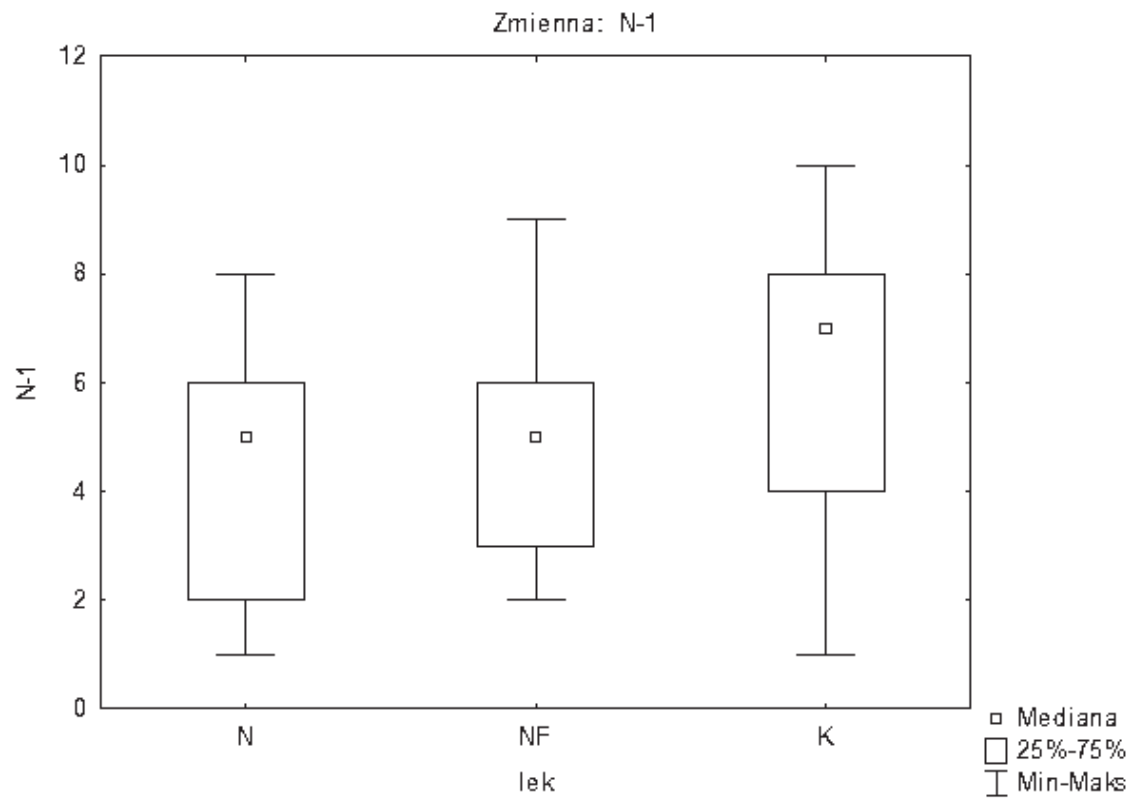

Rycina 3. Porównanie skuteczności działania przeciwbólowego ibuprofenu (NF), ketoprofenu (K) i nimesulidu (N) w skali numerycznej w 24 godzinie po zabiegu. N-1 Skala numeryczna w 24 godzinie od zabiegu

Figure 3. Comparison of analgesic effectiveness of ibuprofen (NF), ketoprofen (K) and nimesulide ( $N$ ) in the 24th hour after surgery in numeric scale. $\mathrm{N}-1$ - numeric scale in the 24th hour after surgery 


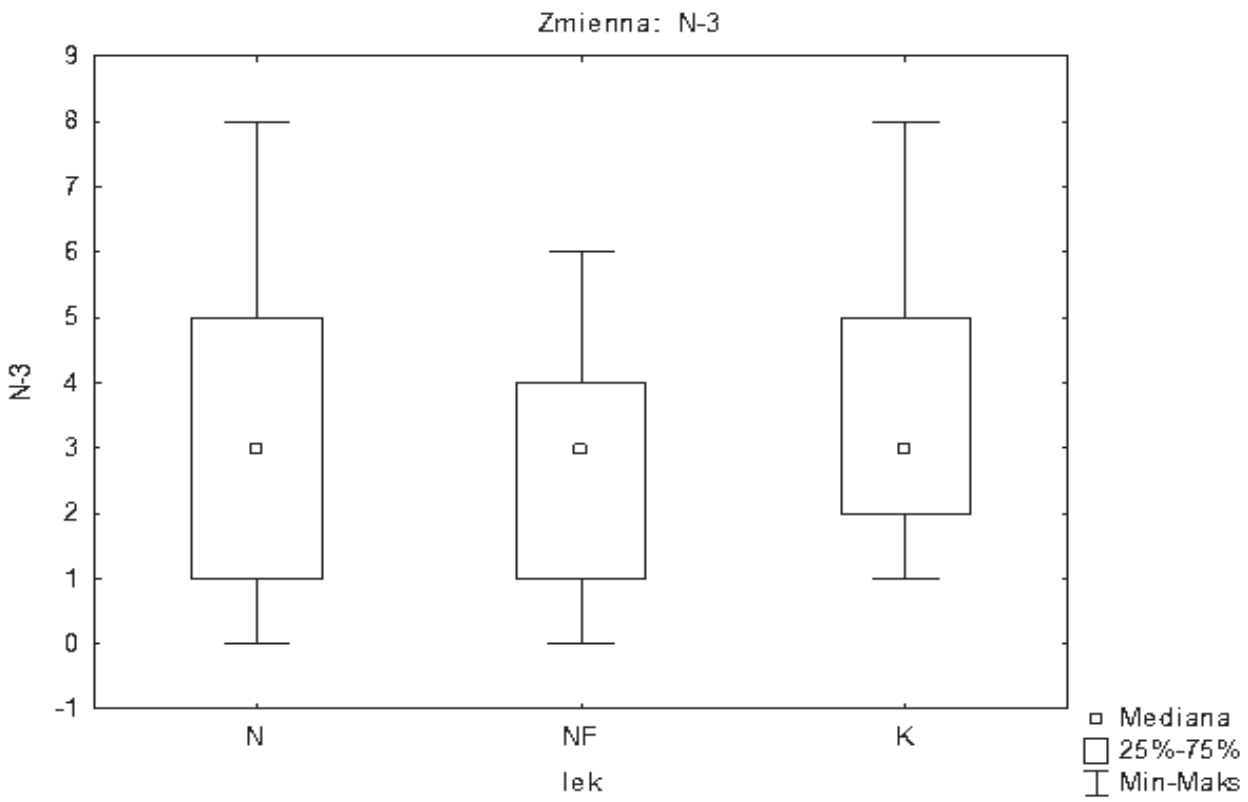

Rycina 4. Porównanie skuteczności działania przeciwbólowego ibuprofenu (NF), ketoprofenu (K) i nimesulidu (N) w skali numerycznej w 72 godzinie po zabiegu. N-3 Skala numeryczna w 72 godzinie od zabiegu

Figure 4. Comparison of analgesic effectiveness of ibuprofen (NF), ketoprofen (K) and nimesulide (N) in the $72 n d$ hour after surgery in numeric scale. N-3 - numeric scale in the 72nd hour after surgery

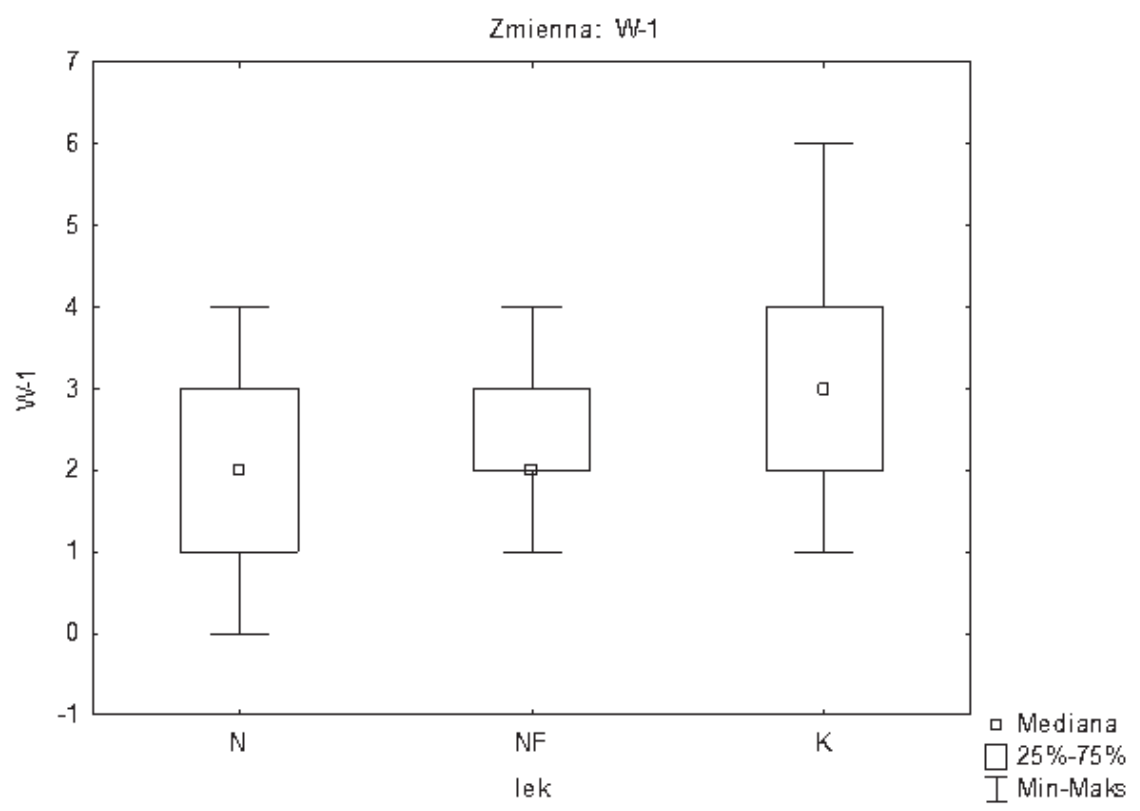

Rycina 5. Porównanie skuteczności działania przeciwbólowego ibuprofenu (NF), ketoprofenu (K) i nimesulidu (N) w skali werbalnej w 24 godzinie po zabiegu. W-1 Skala werbalna w 24 godzinie od zabiegu

Figure 5. Comparison of analgesic effectiveness of ibuprofen (NF), ketoprofen (K) and nimesulide (N) in the 24th hour after surgery in verbal scale. W-1 - verbal scale in the 24th hour after surgery 
Zmienna: Wh-3

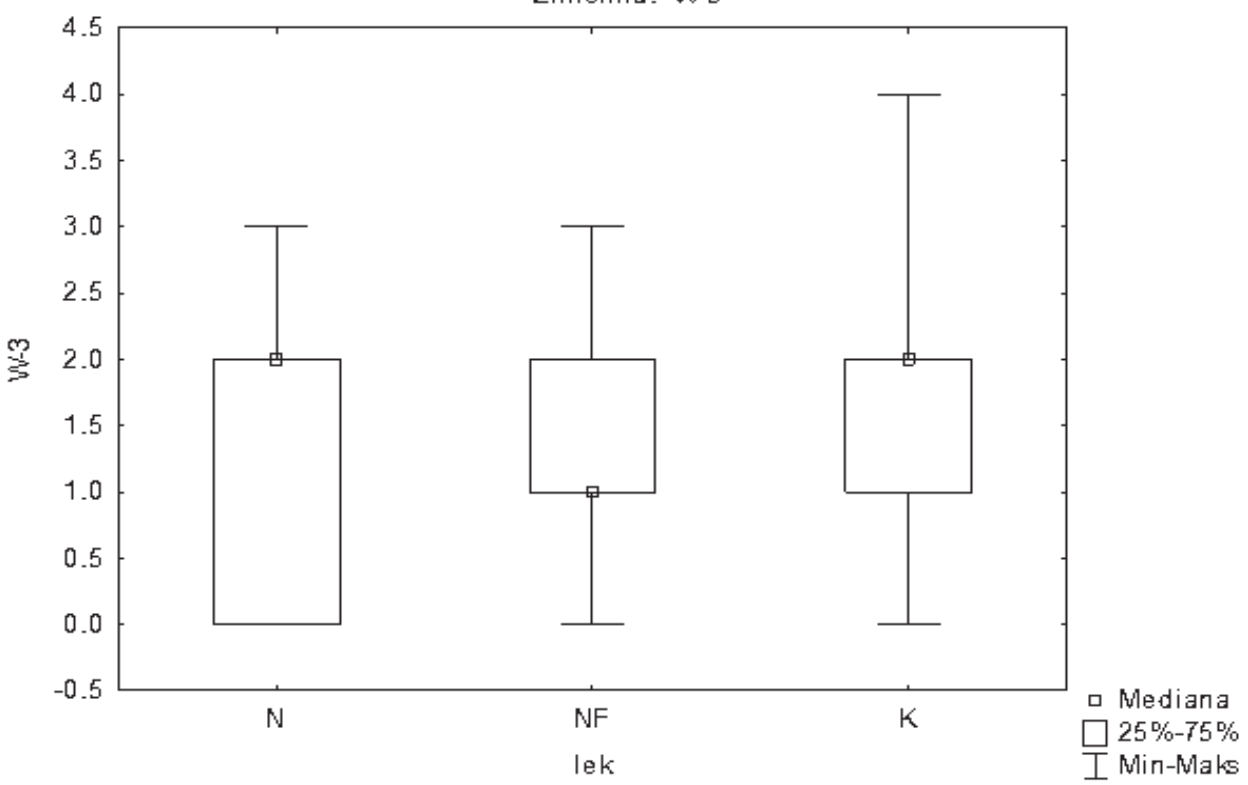

Rycina 6. Porównanie skuteczności działania przeciwbólowego ibuprofenu (NF), ketoprofenu (K) i nimesulidu (N) w skali werbalnej w 72 godzinie po zabiegu. W-3 Skala werbalna w 72 godzinie od zabiegu

Figure 6. Comparison of analgesic effectiveness of ibuprofen (NF), ketoprofen (K) and nimesulide (N) in the 72nd hour after surgery in verbal scale. W-3 - verbal scale in the 72nd hour after surgery

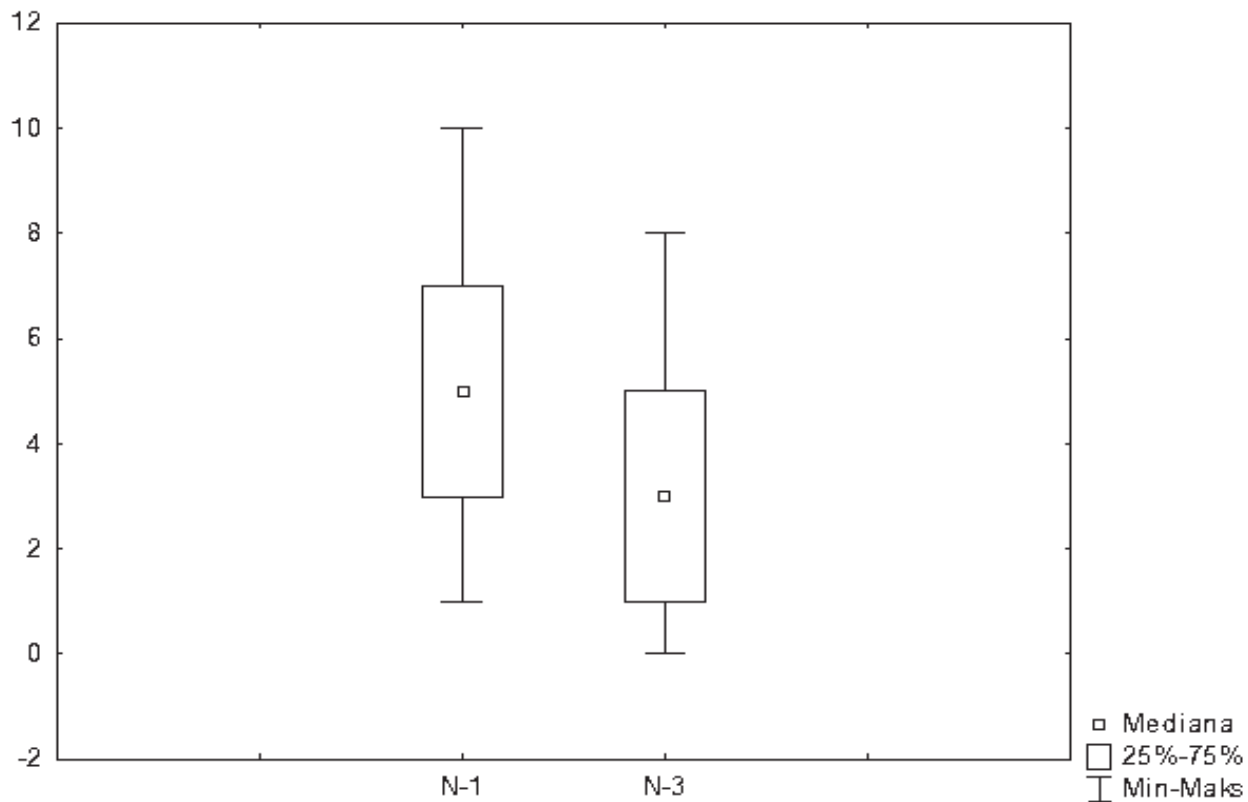

Rycina 7. Zbiorcze porównanie skuteczności działania przeciwbólowego w 24 (W-A1) i 72 (W-A3) godzinie po zabiegu wyrażane przy pomocy skali wizualno-analogowej.

Figure 7. Comparison of analgesic effectiveness in the 24th hour (W-A1) and in the 72nd hour (W-A3) after surgery presented in visual analog scale. 


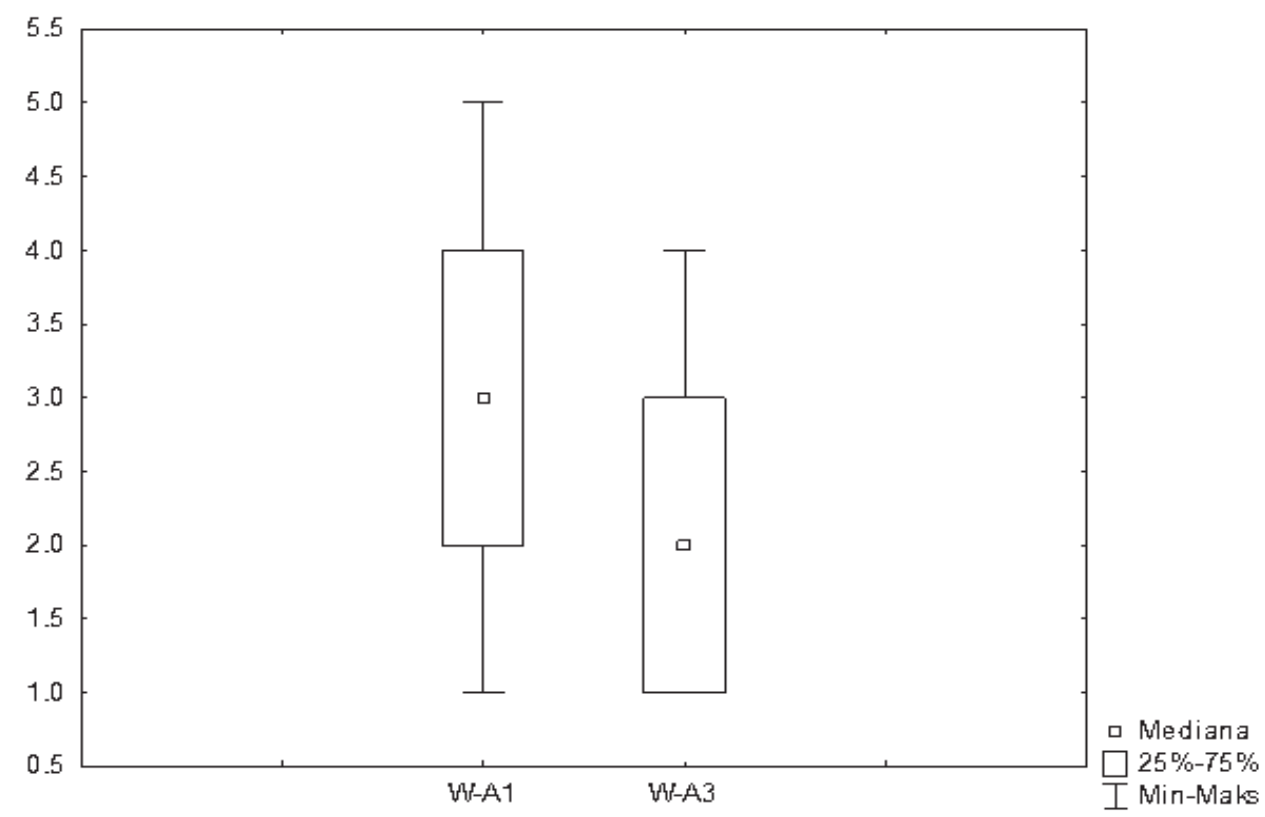

Rycina 8. Zbiorcze porównanie skuteczności przeciwbólowej leków w 24 (N-1) i 72 (N-3) godzinie po zabiegu, wyrażone przy pomocy skali numerycznej.

Figure 8. Comparison of analgesic effectiveness in the 24th hour (N-1) and in the 72nd hour (N-3) after surgery presented in numeric scale

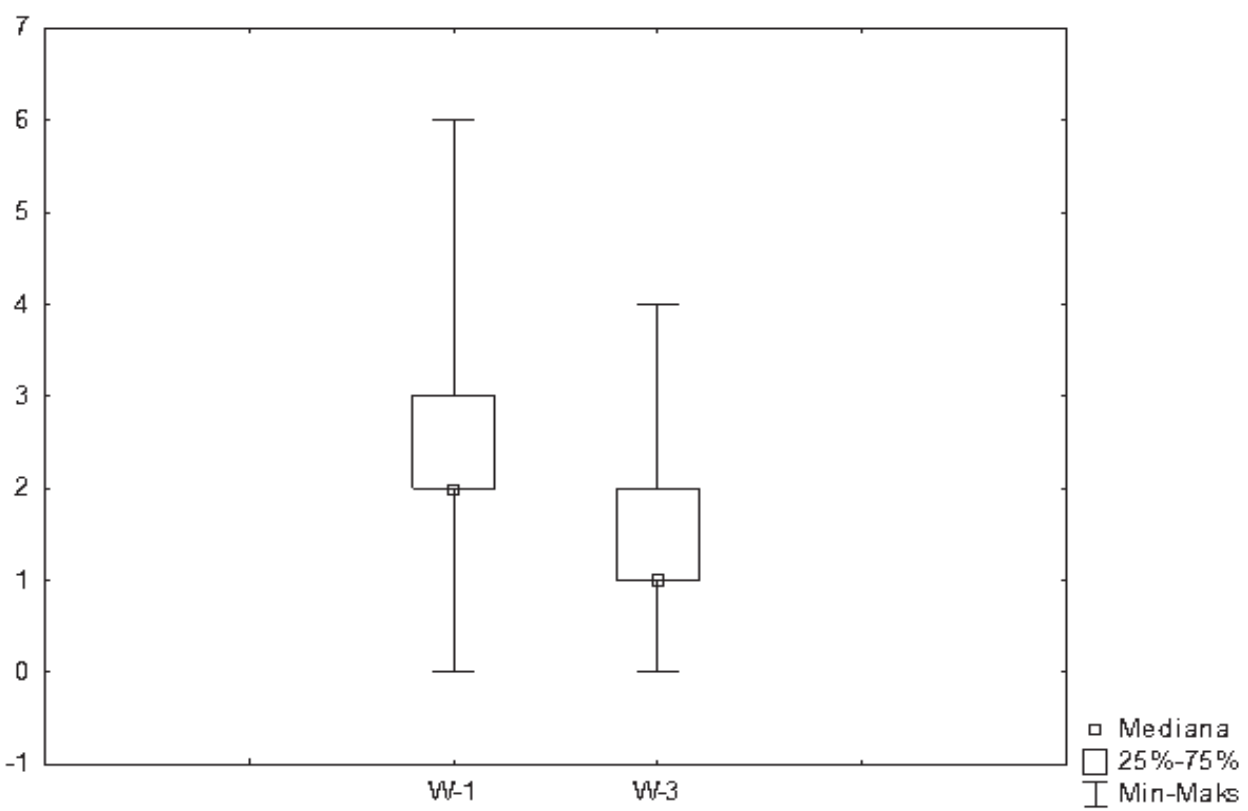

Rycina 9. Zbiorcze porównanie skuteczności przeciwbólowej leków w 24 (W-1) i 72 (W-3) godzinie po zabiegu wyrażone przy pomocy skali werbalnej

Figure 9. Comparison of analgesic effectiveness in the 24th hour (W-1) and in the 72nd hour (W-3) after surgery presented in verbal scale 
Tabela. 1. Porównanie wszystkich skal w 24 godzinie po zabiegu: wizualno-analogowej W-A1, numerycznej $\mathrm{N}-1$, werbalnej $\mathrm{W}-1$

Table. 1. Comparison of all scales - visual analog (W-A 1), numeric ( $N-1)$ and verbal $(W-1)$ - in the 24th hour after surgery.

\begin{tabular}{|l|c|c|c|c|}
\hline & N-Ważnych & R - Spearman & $t(\mathrm{~N}-2)$ & $p$ \\
\hline W-A1 \& N-1 & 58 & 0,922983 & 17,94766 & 0,000000 \\
\hline W-A1 \& W-1 & 58 & 0,862282 & 12,74164 & 0,000000 \\
\hline N-1 \& W-1 & 58 & 0,895604 & 15,06585 & 0,000000 \\
\hline
\end{tabular}

Tabela 2. Porównanie wszystkich skal w 72 godzinie po zabiegu: wizualno-analogowej $\mathrm{W}-\mathrm{A} 3$, numerycznej $\mathrm{N}-3$, werbalnej $\mathrm{W}-3$.

Table 2. Comparison of all scales - visual analog ( $W-A$ 3), numeric (N-3) and verbal $(W-3)$ - in the $72 n d$ hour after surgery.

\begin{tabular}{|l|c|c|c|c|}
\hline & N-Ważnych & R-Spearman & $t(\mathrm{~N}-2)$ & $\mathrm{p}$ \\
\hline W-A3 \& N-3 & 58 & 0,911442 & 16,57784 & 0,000000 \\
\hline W-A3 \& W-3 & 58 & 0,806935 & 10,22372 & 0,000000 \\
\hline N-3 \& W-A3 & 58 & 0,911442 & 16,57784 & 0,000000 \\
\hline
\end{tabular}

[8]. Ze względu na dostępność i bezpieczeństwo stosowania ibuprofen stosowany samodzielnie lub w skojarzeniu z paracetamolem stanowi złoty standard leczenia przeciwzapalnego.

Do silnie- i krótkodziałających NLPZ należy ketoprofen. Jest szybko wchłaniany z przewodu pokarmowego i osiąga maksymalne stężenie w osoczu w czasie 0,5-2 godzin od podania. Jego mechanizm działania przeciwzapalnego polega na hamowaniu COX-1, inhibicji aktywności 5-lipooksygenazy i hamowaniu neutrofilów. Jest dobrze tolerowany u pacjentów $z$ astmą aspirynową, ale ujemną stroną jego stosowania są częste niepożądane objawy gastryczne. W naszych badaniach ketoprofen powodował również najwięcej efektów ubocznych. Pacjenci zgłaszali głównie nudności, bóle brzucha i osłabienie. Ketoprofen wykazuje działanie antyagregacyjne, wydłużając czas krwawienia. W naszych badaniach nie wykazywał statystycznie znamiennej wyższej skuteczności działania przeciwbólowego niż ibuprofen i nimesulid. Naszym zdaniem znaczny wpływ na uzyskane wyniki miał zastosowany schemat podawania i charakter procesu zapalnego, który był źródłem bólu. Pochodzące z piśmiennictwa sprzeczne wyniki dotyczące skuteczności ketoprofenu wynikały często ze stosowania różnych schematów podawania leku w różnych przypadkach klinicznych. W dawce 50 mg ketoprofen wykazywał podobny efekt antyagregacyjny jak diklofenak w dawce $25 \mathrm{mg}$ [9]. Może być także łączony $z$ acetoaminofenem w kombinacji 100 mg ketoprofenu z $1000 \mathrm{mg}$ acetoaminofenu. Takie połączenie okazało się skuteczniejsze niż podawanie samego ketoprofenu i powodowało zdecydowanie szybszy początek działania przeciwbólowego przy podobnych objawach ubocznych [10, 11]. Doustne stosowanie ketoprofenu w dawce $300 \mathrm{mg}$ na dzień obniżało o $22 \%$ konieczność stosowania fentanylu i innych opioidów w okresie 20 godzin po rozległych zabiegach ortopedycznych. Nie redukowało to jednak w żaden sposób objawów ubocznych opioidów [12]. Niejednokrotnie porównuje się skuteczność działania przeciwbólowego NLPZ stosowanych przed zabiegami chirurgicznego usuwania dolnych zębów mądrości, jak i po zabiegach. Ketoprofen zastosowany po 60 min od zabiegu powodował opóźnienie działania przeciwbólowego w porównaniu z ketoprofenem stosowanym 60 min przed zabiegiem, ale w ciągu 12 godzin zapewniał zdecydowanie lepszą kontrolę bólu. Nawet dłuższe podawanie ketoprofenu przez 2 dni przed planowanym zabiegiem nie wpływało na poprawę jego działania przeciwbólowego w porównaniu ze standardowym jego aplikowaniem po zabiegu przez okres 3 dni [13]. Znikomą skuteczność podawania ketoprofenu w dawce $150 \mathrm{mg}$ na dwa dni przed planowanym zabiegiem wykazali również Liporaci i wsp. [14]. Ketorolak w dawkach $10 \mathrm{mg}$ i 20 mg jest bardziej skuteczny niż ketoprofen $w$ dawce $50 \mathrm{mg}$ [15]. Nie odnotowuje się także statystycznie znamiennych różnic $w$ skuteczności działania przeciwbólowego pomiędzy ketoprofenem $w$ dawce $100 \mathrm{mg}$ podawanym dożylnie a metyloprednizolonem w dawce $1 \mathrm{mg} / \mathrm{kg}$ masy ciała [16].

Inny mechanizm działania przeciwbólowego i przeciwzapalnego reprezentuje nimesulid, który jest preferencyjnym inhibitorem COX-2. Hamuje powstawanie enzymów z grupy metaloproteinaz, takich jak kolagenaza i stromelizyna. Zmniejsza 
aktywność fosfolipazy A2 i uwalnianie histaminy. Levrini i wsp. porównując skuteczność kilku niesteroidowych leków przeciwzapalnych po zabiegach usuwania zatrzymanych dolnych zębów mądrości, wykazali, że nimesulid jest bardzo skuteczny w redukowaniu bólu w dniu zabiegu, przedłuża czas bez bólu, a najlepsze wyniki terapeutyczne są osiągane, kiedy pacjent przyjmie lek jeszcze przed początkiem jego odczuwania [17]. Facchini i wsp. porównując ketoprofen i nimesulid, wskazują na podobny efekt terapeutyczny, ale jednocześnie mniejszą liczbę efektów ubocznych w przypadku nimesulidu [18], co zostało również wykazane w naszych badaniach. O jego silnych właściwościach przeciwbólowych świadczą pozytywne efekty terapeutyczne u pacjentów cierpiących na artropatie stawów skroniowo-żuchwowych czy neuralgię nerwów czaszkowych. Ragot i wsp., badając efektywność stosowania nimesulidu w redukcji bólu po zabiegach w chirurgii stomatologicznej, nie wykazali istotnej różnicy pomiędzy dawką 100 mg i 200 mg [19]. Nimesulid i inne selektywne inhibitory COX-2 mogą być łączone z lekami sterydowymi, co zwiększa skuteczność ich działania [20].

We wszystkich stosowanych przez nas skalach ból był słabszy w 72 godzinie po zabiegu niż w 24 godzinie. Świadczy to o przechodzeniu fazy zapalenia pooperacyjnego, charakterystycznej dla pierwszego okresu po zabiegu, w faze gojenia. Faza zapalenia jest integralną częścią procesu gojenia pozabiegowego. Czas jej trwania zależy od czynników miejscowych i ogólnoustrojowych. Atraumatyczne przeprowadzenie zabiegu, właściwe zaopatrzenie rany pozabiegowej, brak schorzeń ogólnoustrojowych oraz wdrożona antybiotykoterapia niewątpliwie wpłynęła na maksymalne skrócenie fazy zabiegowej i mobilizację układu immunologicznego, charakterystyczną dla tej fazy.

Wykorzystane w naszych badaniach skale do oceny bólu wykazały się podobną skutecznością, czułością i przydatnością terapeutyczną i mogą być zamiennie stosowane w pooperacyjnym monitorowaniu bólu. W naszej ocenie podstawowym kryterium w ich wyborze powinna być przejrzystość i łatwość w opisywaniu bólu przez pacjenta, co później przekłada się na łatwiejszy odczyt wyników przez lekarza. Konstrukcja skali powinna ograniczyć możliwość niejednoznaczności oceny i być zrozumiała dla pacjenta.

\section{Wnioski}

Wobec zbliżonej efektywności przeciwbólowej badanych leków podstawą ich wyboru i stosowania powinny być indywidualnie określone wskazania i przeciwskazania, a w szczególności wywoływa- ne przez nie efekty uboczne. Niezwykle ważne jest jak najwcześniejsze wdrożenie terapii przeciwbólowej $\mathrm{i}$ jej systematyczne stosowanie zgodne $z$ instrukcją. Skale do oceny bólu pooperacyjnego są przydatnym narzędziem w jego diagnostyce i monitorowaniu w okresie pooperacyjnym.

\section{Oświadczenia}

\section{Oświadczenie dotyczące konfliktu interesów}

Autorzy deklarują brak konfliktu interesów w autorstwie oraz publikacji pracy.

\section{Źródła finansowania}

Autorzy deklarują brak źródeł finansowania.

\section{Piśmiennictwo}

[1] Kaczmarzyk T, Goszcz A, Stypułkowska J, Woroń J, Zaleska M. Współczesna farmakoterapia w schorzeniach chirurgicznych jamy ustnej i tkanek okolicznych. Farmakoterapia bólu w chirurgii stomatologicznej I szczękowo-twarzowej. Wydawnictwo Uniwersytetu Jagielońskiego. Kraków; 2006 s 171-213.

[2] Jamison RN, Gracely RH, Raymond SA, Levine JG, Marino B, Herrmann TJ, Daly M, Fram D, Katz NP. Comparative study of electronic vs. paper VAS ratings: a randomized, crossover trial using healthy volunteers. Pain. 2002;99(1-2):341-347.

[3] Williamson A, Hoggart B. Pain: a review of three commonly used pain rating scales. J Clin Nurs. 2005;14(7):798-804.

[4] Ferreira-Valente MA, Pais-Ribeiro JL, Jensen MP. Validity of four pain intensity rating scales. Pain. 2011;152(10):2399-2404.

[5] Gallagher EJ, Liebman M, Bijur PE. Prospective validation of clinically important changes in pain severity measured on a visual analog scale. Ann Emerg Med. 2001;38(6):633-638

[6] Weil K, Hooper L, Afzal Z, Eposito M, Worthington HV, van Wijk $A$, Coulthard P. Paracetamol for pain relief after surgical removal of lower wisdom teeth (Review). Cochrane Database. 2007;CD004487:1-37.

[7] Merry AF, Gibss RD, Edwards J, Ting GS, Frampton C, Davies E, Anderson BJ. Combined acetoaminophen and ibuprofen for pain relief after oral surgery in adults: a randomized controlled trial. Br J Anaesth. 2010;104(1): 80-88.

[8] Lustenberger FD, Grätz KW, Mutzbauer TS. Efficacy of ibuprofen versus lornoxicam after third molar surgery: a randomized, double-blind, crossover pilot study. Oral Maxillofac Surg. 2011;15:57-62.

[9] Naclério-Homem MG, Deboni MC, Rapoport A, Chin VK. Effects of ketoprofen and diclofenac potassium on blood coagulation tests after removal of third molars. Quintessence Int. 2009;40(4):321-325.

[10] Akural El, Järvimäki V, Länsineva A, Niinimaa A, Alahuhta S. Effects of combination treatment with ketoprofen 100 $\mathrm{mg}+$ acetomainophen. $1000 \mathrm{mg}$ on postoperative dental pain: a single-dose, 10-hour, randomized, double-blind, active- and placebo-controlled clinical trial. Clin Ther. 2009;31(3):560-8.

[11] Karvonen S, Salomäki T, Olkkola KT. Efficacy of oral paracetamol and ketoprofen for pain management after major orthopedic surgery. Methods Find Exp Clin Pharmacol. 2008;30(9):703-706.

[12] Cooper SA, Reynolds DC, Reynolds B, Hersh EV. Analgesic efficacy and safety of $(R)$ - ketoprofen in postoperative dental pain. J Clin Pharmacol. 1998;38(2 suppl):11S-18S.

[13] Kaczmarzyk T, Wichliński, Stypułkowska J, Zaleska, Woron. Preemptive effect of ketoprofen on postoperative pain following third molar surgery. A prospective, rando- 
mized, double-blinded clinical trial. Int J Oral Maxillofac Surg. 2010;39(7):647-652.

[14] Liporaci JL. Assessment of preemptive analgesia efficacy in surgical extraction of third molars. Rev Bras Anestesiol. 2012;62(4):502-510.

[15] Olmedo MV, Gálvez R, Vallecillo M. Double-blind parallel comparison of multiple doses of ketorolac, ketoprofen and placebo administered orally to patients with postoperative dental pain. Pain. 2001;90(1-2):135-41.

[16] Leone M, Richard O, Antonini F, Rousseau S, Chabaane W, Guyot L, Martin C. Comparison of methylprednisolone and ketoprofen after multiple third molar extraction: a randomized controlled study. Oral Surg Oral Med Oral Pathol Oral Radiol Endod. 2007;103(1):7-9.

[17] Levrini L, Carraro M, Rizzo S, Salgarello S, Bertelli, Pelliccioni GA, Garau V, Bandettini M, Caputi S, Lörincz A, Szûcs A. Prescriptions of NSAIDs to patients undergoing third molar surgery: an observational, prospective, multicentre survey. Clin Drug Investig. 2008;28(10):657-668.

[18] Facchini R, Selva G, Perreti G. Tolerabity of nimesulide and ketoprofen in paediatic patients with traumatic or surgical fractures. Drugs. 1993;46(Suppl. 1):238-241.
[19] Ragot JP, Monti T, Macciocchi A. Controlled clinical investigation of acute analgesic activity of nimesulide in pain after oral surgery. Drugs. 1993;46(6):162-167.

[20] Selimovic E, Ibrahimagić-Šeper L, Petričević N, Nola-Fuchs P. Pain relieve after impacted wisdom teeth extraction dependent on the drug therapy. Coll. Antropol. 2011;35:133-136.

Zaakceptowano do edycji: 2017-09-01 Zaakceptowano do publikacji: 2017-11-02

\section{Adres do korespondencji:}

Katarzyna Błochowiak

Katedra i Klinika Chirurgii Stomatologicznej

Uniwersytet Medyczny im. Karola Marcinkowskiego

w Poznaniu

ul. Bukowska 70, 60-812 Poznań

e-mail: kasia@naszdentysta.com.pl 